\title{
Toolkit for Monitoring the Region's Tax Security
}

\author{
Liubov V. Perekhrestova \\ Volgograd State University \\ Institute of Economics and Finance \\ Department of Theory of Finance, Credit and Taxation \\ Volgograd, Russia \\ PerekrestovaLV@volsu.ru
}

\author{
Elena S. Starostina \\ Volgograd State University \\ Institute of Economics and Finance \\ Department of Theory of Finance, Credit and Taxation \\ Volgograd, Russia \\ $\underline{\text { StarostinaES@ volsu.ru }}$
}

\author{
Nickolay P. Bragin \\ Volgograd State University \\ Institute of Economics and Finance \\ Department of Theory of Finance, Credit and Taxation \\ Volgograd, Russia \\ BraginNP@ volsu.ru
}

\begin{abstract}
The article is devoted to the development of a methodological toolkit for monitoring tax security at the level of the Russian Federation constituent entities. The definition of tax security is formulated with reference to the regional level of the economy, besides, structural blocks of tax security monitoring are presented. Based on the systematization of tax security threats into economic, institutional, organizational and behavioral, a block monitoring model has been developed. As a methodological toolkit for monitoring the tax security of the region the threat indicators for each selected group were proposed. Groups of real threats to the tax security of a particular region were empirically identified; they are as follows: institutional, organizational and behavioral.
\end{abstract}

Keywords - toolkit, external threats, internal threats, indicator, monitoring, tax security, indicator, region

\section{INTRODUCTION}

The financial security of the Russian Federation constituent entities is an elaborate complex of investment, monetary-credit and budget-tax security subsystems that, in aggregate, can ensure the stable functioning of the regional economy. The most important component of the financial security system is the tax security subsystem, as a stable, fixed, efficient tax system guarantees the formation of the revenue side of all budget levels sufficient to meet the expenditure commitments.

Under the tax safety of the region the state of the tax system which ensures guaranteed protection of tax interests of the federation subjects, municipalities and taxpayers from internal and external threats are understood. When regional tax security is gained, the tax interests of the state, local communities, business, public organizations, as well as households and individuals, are consolidated.
Tax security monitoring is a continuous process of supervision and recording the parameters of the regional tax system as well as the state of its security in comparison with the specified criteria.

In the economic theory and practice there is no common approach to the monitoring regional tax security system organization, although sufficient tax resources of regional budgets predetermine the level of expenditure obligations discharge, the solution of economic and social problems.

The most difficult and practically significant task is the tax safety indicators development, on the bases of which continuous and solid supervision should be organized, moreover, these indicators should have safe value criteria, signaling the transition of potential threatening security factors into real threats.

The article is aimed at developing a toolkit for monitoring the tax safety of the regions in the form of indicators and their thresholds, systematized by security threats blocks, and its approbation of a four-factor model for regional tax security monitoring on a specific subject of the Russian Federation.

\section{MATERIALS AND Methods (MODEL)}

The research was carried out within the framework of a systematic approach with the use of general scientific methods: analysis and synthesis, induction and deduction, scientific abstractions. The methods of statistical and economic analysis are applied: data collection; data processing by groupings, series of dynamics, relative values of tabular modeling; comparisons, analogies, objective logic results analysis.

The data of tax statistics and the materials of previous researches made by the authors of the article formed the information basis of the paper [1], [2]. 


\section{RESULTS AND DISCUSSION}

Tax security monitoring is a continuous process of supervision and recording the parameters of the regional tax system and the state of its security in comparison with the specified criteria.

Monitoring of the regional tax system parameters continuous supervision of absolute and relative indicators of the regional budget tax revenues to obtain a set of measured values of parameters in time intervals during which the values of the parameters do not change significantly.

Monitoring the tax security state - monitoring the state of regional tax system in order to determine and predict the moment of its transition into dangerous (critical, limiting state). The result of the tax security state monitoring is a set of diagnoses that are put by monitoring subjects (experts), it means that, the principal difference between state monitoring and parameters monitoring is the interpretation of the measured parameters in terms of safety thresholds, in other words, the expert support for making decisions on the tax policy correction.

\section{A. Grouping the Tax Security of the Regions Threats for Building a Monitoring Indicators Block Model}

The tax security threats have different origins. On this basis such threats as: 1) threats to reduce economic and tax potential (economic); 2) threats caused by changes in tax legislation (institutional); 3) threats caused by deficiencies in tax administration (organizational); 4) threats of opportunistic behavior of taxpayers (behavioral) - can be singled out.

Threats of an economic nature are caused by a decline in production, an increase in the number of unprofitable enterprises, and a decrease in the incomes of the population. These negative trends affect the tax potential of the region weakening.

Indicators of such threats are the growth rate of the gross regional product (GRP), the dynamics of the tax revenues share in GRP and the share of tax revenues in budget revenues.

Economic threats tracking is the task and content of the first unit of monitoring the tax security of the federation subjects.

Threats caused by changes in tax legislation may be external to the region and internal, defined by regional laws. External threats appear due to a decrease in the regional budget potential due to an imbalance in the amount of financing between the center and the regions. The indicator of such threats is the volume of tax revenues of the regional budget that forms the object of the tax security monitoring second block.

The drawbacks of tax administration lead to a sharp decrease in tax revenues into the budget, increase the likelihood of tax violations, infract the balance of intergovernmental fiscal relations between regions and the Federal Center and, ultimately, build social tensions in the society.
The third group of threats to regional tax security is connected with tax administration.

The indicators of these threats are deviations of planned tax revenues from those actually received in the regional budget and an increase in tax arrears.

The growth of taxpayers' debts to the budget is largely due to their opportunistic behavior, tax evasion, tax offenses and crimes [3], [4], [5].

To monitor the threats of opportunistic behavior, the fourth block of tax security monitoring is designed. The complexity of this observation lies in the variety of reasons and methods for evading taxes. More sophisticated methods of such evasion have appeared recently. For example, the conduct of financial transactions through offshore and the manipulation of transfer pricing. Consequently, the indicators of monitoring and fixing tax offenses and crimes can be too large presenting a collection of limited reliability, as tax evasion is carefully concealed by unscrupulous taxpayers. The reliable information on tax violations can be obtained only from official reports on the tax control results. This is the form 2-NC "Report on the results of tax authorities control work". The number of field and desk inspections that revealed violations, the amount of additional assessed payments based on the results of inspections and the amount of fines and penalties in the additional assessed amount of payments should become the indicators of the fourth monitoring unit. These indicators in aggregate will reflect the scale of tax violations and potential damage to the region tax system from the opportunistic behavior of taxpayers.

\section{B. Toolkit for Monitoring the Tax Security of the Region Approbation}

The monitoring indicators approbation was carried out on the example of the Volgograd region (Russian Federation).

The indicators of the first monitoring unit are presented in Table I.

TABLE I. IndiCATORS OF ECONOMIC THREATS to TAX SECURITY

\begin{tabular}{|l|l|c|c|}
\hline \multicolumn{1}{|c|}{ Indicator } & \multicolumn{3}{|c|}{ Years } \\
\cline { 2 - 4 } & \multicolumn{1}{|c|}{$\mathbf{2 0 1 4}$} & $\mathbf{2 0 1 5}$ & $\mathbf{2 0 1 6}$ \\
\hline $\begin{array}{l}\text { Gross regional product (GRP), mln. } \\
\text { rub. }\end{array}$ & 715.4 & 777.8 & 813.6 \\
\hline GRP growth rate, \% & $\mathrm{X}$ & 108.7 & 104.6 \\
\hline $\begin{array}{l}\text { Budget consolidated revenues, mln. } \\
\text { rub. }\end{array}$ & 113.5 & 121.8 & 123.5 \\
\hline $\begin{array}{l}\text { Budget consolidated revenues } \\
\text { growth rate, \% }\end{array}$ & $\mathrm{X}$ & 107.3 & 101.4 \\
\hline $\begin{array}{l}\text { Budget consolidated tax revenues, } \\
\text { mln. rub. }\end{array}$ & 74.4 & 79.0 & 87.0 \\
\hline Tax revenues growth rate, \% & $\mathrm{X}$ & 106.2 & 110.1 \\
\hline Tax income share in GRP, \% & 10.4 & 10.2 & 10.7 \\
\hline $\begin{array}{l}\text { Tax revenues share in consolidated } \\
\text { budget revenues, \% }\end{array}$ & 65.6 & 64.9 & 70.4 \\
\hline \multicolumn{3}{|c|}{ a. Compiled by the authors [6,7]. }
\end{tabular}




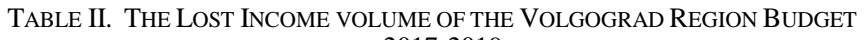
IN 2017-2019.

\begin{tabular}{|l|c|}
\hline \multicolumn{1}{|c|}{ Changes in tax legislation } & $\begin{array}{c}\text { The volume } \\
\text { of falling } \\
\text { income, mln. } \\
\text { rub. }\end{array}$ \\
\hline $\begin{array}{l}\text { The decision taken at the Federal Level to reduce tax } \\
\text { rate for corporate profit tax from 18\% to 17\% from } \\
\text { January 1, 2017 }\end{array}$ & 3.8 \\
\hline $\begin{array}{l}\text { Tax and non-tax revenues reduction by the creation } \\
\text { of consolidated groups of taxpayers }\end{array}$ & 9.6 \\
\hline $\begin{array}{l}\text { Losses from tax privileges established at the Federal } \\
\text { Level on taxes coming into the regional budget }\end{array}$ & 9.3 \\
\hline $\begin{array}{l}\text { The norm of enrollment in the budgets of the } \\
\text { constituent entities of the Russian Federation from } \\
\text { the receipt of excises on oil products reduction }\end{array}$ & 8.0 \\
\hline \multicolumn{2}{|c|}{ Compiled by the authors [6] } \\
\hline
\end{tabular}

The values of the indicators presented in the table indicate the absence of economic threats to the tax security of the Volgograd region in the analyzed period. The growth rates in GRP, revenues of the consolidated budget, tax revenues exceed 100 per cent. The share of tax revenues in GRP and revenues of the consolidated budget is stable, since after an insignificant recession in 2015 set by the impact of economic sanctions, it exceeded the level of 2014.

Threats caused by changes in tax legislation, which are indicated by the volume of tax revenues of the regional budget, are presented in Table II.

The significance of these threats can be assessed by comparing the volume of falling revenues with the planned value of the regional budget revenues for the same period.

Revenues are planned "for 2017 in the amount of 73.1 billion rubles, 2018 - 75.1 billion rubles, 2019 - 77.7 billion rubles". [8]. Falling incomes in the amount of 30.7 billion rubles. account for $13.6 \%$ of the regional budget revenues for the three planned years (225.9 billion rubles). Such losses of incomes of the regional budget can be considered as a clear threat to tax security, as the share of these falling incomes approximates the share of income from the corporate income tax budget (approximately 16\%).

Tax administration is, first, bringing the process of levying taxes, arising relations between the representatives of tax authorities and taxpayers in accordance with the changed production relations and forms of economic management. And, secondly, it is a set of procedures that provide state administration in the field of taxation, aimed at the legislation on taxes and fees implementation, ensuring the effective functioning of the tax system and tax control. The third group of threats to regional tax security is connected with tax administration.

The indicators of threats related to deficiencies in tax administration are presented in Table III.

Tax administration imperfection represents a significant real threat to the tax security of the region. The debt to the budget growth rate for taxes and fees is much higher than the growth rate of tax revenues (see Table I), with the arrears growing at an accelerating pace both to tax revenues and to debt that can be recovered.

This situation is typical for the Russian Federation as a whole.

TABLE III - INDICATORS OF THREATS CONCERNED BY TAX ADMINISTRATION FAILURE

\begin{tabular}{|l|c|c|}
\hline \multicolumn{1}{|c|}{ Indicator } & $\begin{array}{c}\mathbf{2 0 1 5} / \\
\mathbf{2 0 1 4}\end{array}$ & $\begin{array}{c}\mathbf{2 0 1 6} \text { / } \\
\mathbf{2 0 1 5}\end{array}$ \\
\hline $\begin{array}{l}\text { The debt to the budget for taxes and dues } \\
\text { growth rate total, } \%\end{array}$ & 115.8 & 119.4 \\
\hline $\begin{array}{l}\text { The possible growth rate of the debt } \\
\text { collection, \% }\end{array}$ & 115.5 & 119.8 \\
\hline The growth rate of arrears, \% & 113.9 & 124.6 \\
\hline
\end{tabular}

"The FTS Duty on Incomes in 2016 increased by more than $20 \%$, reaching 1.4 trillion rubles, the Accounting Chamber reported on the results of the department audit. Moreover, in the House noted the growth of arrears and a decrease in the efficiency of tax collection" [8].

Considerable attention to improving the quality of budget revenues administration has been given in the "Main Directions of the Budget, Tax and Customs Tariff Policy for 2018 and the Planning Period of 2019 and 2020". "Since 2017, under the jurisdiction of Russia Ministry of Finance there are tax administrators that ensure the collection of $90 \%$ of the budget system revenues. The key task for the coming years is the creation of an administrative system built on a single methodological and information basis, which will ensure an increase in the collection of taxes and a reduction in the administrative burden for a fair business" [9]. To reach this aim, a full coverage (from July 1, 2018) of the retail trading network with cash register equipment (CRE) is planned, which provides online data transfer to the FTS servers; the integration of information systems and tax and customs authorities risk management systems; the integration of state off-budget funds and tax service information files; gradual distribution of tracking systems (USAIS - Unified State Automated Information System, marking) into other commodity groups; autoexchange of tax information and a number of other measures.

The threat to the region tax security can also be increased by the costs of tax administration. To neutralize this threat to the Russian Federation tax policy for the next three-year period the measures that facilitate administration and reduce administrative costs are provided. These measures are related to the use of electronic services; taxes payments and payments through the MFC (Multifunctional Center); using the institution of "payment clarification"; introduction of the Institute of Special Advance Contributions; the list of grounds for granting a deferral (installment plan) providing the payments established by the Tax Code expansion; ensuring the certainty of personal income taxation, etc.

The results of tax authorities control work will allow to monitor of the fourth block of tax security in the region indicators. The indicators are presented in Table IV. 
TABLE IV. INDICATORS OF TAXPAYERS OPPORTUNISTIC BEHAVIOR THREAT

\begin{tabular}{|l|l|l|l|}
\hline \multicolumn{1}{|c|}{ Indicator } & \multicolumn{3}{|c|}{ Years } \\
\cline { 2 - 4 } number of on-site tax & 722 & 648 & 1037 \\
\hline $\begin{array}{l}\text { The } \\
\text { inspections that revealed violations, } \\
\text { unit. }\end{array}$ & & & \\
\hline $\begin{array}{l}\text { The growth rate of exit tax } \\
\text { inspections which revealed the } \\
\text { violations \% }\end{array}$ & & 89.8 & 160.0 \\
\hline $\begin{array}{l}\text { Additional payments that were } \\
\text { accrued based on the results of field } \\
\text { audits, mln. rub. }\end{array}$ & 4323.7 & 4461.2 & 6087.3 \\
\hline $\begin{array}{l}\text { Including penalties and fines, } \\
\text { mln.rub. }\end{array}$ & 1060.0 & 1161.4 & 1521.8 \\
\hline $\begin{array}{l}\text { The growth rate of additional } \\
\text { payments based on the results of } \\
\text { on-site inspections, } \%\end{array}$ & $\mathrm{X}$ & 103.2 & 136.4 \\
\hline $\begin{array}{l}\text { The growth rate of penalties and } \\
\text { fines as the result of field } \\
\text { inspections, \% }\end{array}$ & $\mathrm{X}$ & & \\
\hline $\begin{array}{l}\text { The number of cameral tax } \\
\text { inspections that revealed violations, } \\
\text { unit }\end{array}$ & 31610 & 29163 & 34364 \\
\hline $\begin{array}{l}\text { The growth rate of cameral tax } \\
\text { inspections that revealed violations, } \\
\% \text { X }\end{array}$ & & 92.2 & 117.8 \\
\hline $\begin{array}{l}\text { Additional payments that were } \\
\text { accrued based on the results of desk } \\
\text { audits, mln. rub. }\end{array}$ & 978.5 & 1203.4 & 1010.8 \\
\hline $\begin{array}{l}\text { Including penalties and fines, mln. } \\
\text { rub. }\end{array}$ & 111.5 & 205.5 & 233.5 \\
\hline $\begin{array}{l}\text { The additional payments growth } \\
\text { rate based on the results of desk } \\
\text { audits, \% }\end{array}$ & $\mathrm{X}$ & 131.0 \\
\hline $\begin{array}{l}\text { The growth rate of penalties and } \\
\text { fines on the results of desk audits, } \\
\% \text { X }\end{array}$ & & \\
\hline
\end{tabular}

Compiled by the authors [7]

The number of field and desk inspections indicators reflect the lower limit of tax violations quantity, if it is assumed that at least one offense has been detected in each effective audit. The growth of additional taxes assessments, penalties and fines indicates an increase in the revealed tax violations scale. In the Volgograd region, with a multidirectional dynamic of the inspections in the period under study number, the additional accrued payments for on-site inspections are growing at an accelerated rate. The average annual growth rate in 2015-2016 accounted in $119.8 \%$. According to the desk checks, the average annual growth rate of the additional accrued payments accounted in $103.5 \%$. The threats of opportunistic behavior of taxpayers are even more evident in the dynamics of penalties and fines indicators. Their growth clearly evidence violations and tax discipline that the tax authorities have proven. Sanctions for field inspections increased at an average annual rate of $120.3 \%$, and for desk inspections - with an even higher average annual rate of $149.0 \%$. The set of indicators actualizes the problem of threats to opportunistic behavior, the search for more effective tax control forms and the rise of tax culture.

In accordance with the public declaration of the goals and objectives of Russia Federal Tax Service, seven key areas for creating a favorable tax environment are envisaged [10]. This is the implementation of tax control based on risk criteria and encouraging the taxpayer, the payer of insurance premiums to pay their obligations voluntarily; effective resolution of disputes with business, reducing the burden on courts; prevention of bankruptcy application for evading taxes, fees and insurance premiums; creation of comfortable conditions for taxes payments, fees and insurance premiums; carrying out work to increase tax literacy; optimization of procedures related to the registration of legal entities and individual entrepreneurs; expansion of services for the ability of the taxpayer and the payer of insurance premiums to collect information and services via the Internet.

\section{CONCLUSION}

Tax security monitoring is a continuous process of supervision and recording both the parameters of the regional tax system and the state of its security in comparison with the specified criteria.

The importance of the regions tax security monitoring is due to the presence of external and internal security threats, which make it difficult to organize a full use of tax and budget potential of the territory. Only a safe and efficient regional tax system is a reliable basis for the constituent entities of the Russian Federation of their budgetary obligations fulfillment.

According to the sources of the tax security of the region threats, such threats as: 1) threats to reduce economic and tax potential (economic); 2) threats caused by changes in tax legislation (institutional); 3) threats caused by deficiencies in tax administration (organizational); 4) threats of taxpayers' opportunistic behavior (behavioral) - can be singled out. Basing on the threats systematization to tax security into economic, institutional, organizational and behavioral, a fourblock monitoring model has been developed. As a methodological toolkit for monitoring the region tax security, threat indicators for each selected group were proposed.

In the economic block of monitoring such indicators were proposed: the gross regional product growth rate; the share of tax revenues in GRP growth rate and the tax revenues in the regional budget revenues growth rate. The safety criterion is the positive dynamics of the above-mentioned indicators.

As for the institutional block, the indicator of threats to tax security there is the volume of the regional budget falling revenues, determined by changes in tax legislation. The minimization of falling tax revenues is proposed to be considered as a safety criterion.

The fundamental principle of possible tax reforms and measures to adjust the tax system should be the principle of fiscal neutrality, according to which the tax burden on fair taxpayers should not increase. Predictability of all elements of the fiscal system, including tax benefits and non-tax payments, is important.

In the monitoring unit of organizational threats, such indicators as: the debt to the budget for taxes and fees growth rate, the rate of debt growth, possible to recover and the rate of arrears growth - are proposed. It is suggested that the criterion 
of safety is the reduction of all these growth rates and the achievement of a rate of reduction in debts and arrears.

Minimization and total neutralization of the organizational block threats are associated with the improvement of the tax administration quality.

In the block of monitoring the taxpayers opportunistic behavior threats, tax violations are monitored by such indicators as: the number of on-site tax inspections that have revealed violations, the number of desk tax inspections that have revealed violations, the amount of additional assessed payments based on the results of inspections, the amount of penalties and sanctions accrued on the results of tax inspections. The decrease in the growth rates of the number and scale of the revealed tax violations can be the safety criterion.

Tax monitoring toolkit on the example of a specific (Volgograd) region approbation showed real threats to tax security in the institutional, organizational and behavioral blocks. A further study of the tax monitoring toolkit will be aimed at identifying the threshold values of tax security for each indicator at the regional level.

\section{References}

[1] Bragin, N.P. Indikatory ugroz nalogovoj bezopasnosti regiona / N.P. Bragin, L.V. Perekrestova //Aktualэnye problemy teorii i praktiki nalogooblozheniya: Materialy 6 Mezhdunarodnoj nauchno-prakticheskoj konferencii, g. Volgograd, 30 noyabrya $2017 \mathrm{~g}$. - Volgograd: Izd-vo VolGU, 2017. - pp.30-35.

[2] Perekrestova, L.V. Monitoring nalogovoj bezopasnosti regiona / L.V. Perekrestova //Aktual'nye problemy teorii i praktiki nalogooblozheniya: Materialy 6 Mezhdunarodnoj nauchno-prakticheskoj konferencii, g. Volgograd, 30 noyabrya 2017g. - Volgograd: Izd-vo VolGU, 2017. pp. 176-181.

[3] Gaponenko, V.F. Nalogovaya bezopasnost' v sisteme obespecheniya finansovoj bezopasnosti / V.F. Gaponenko, O.V. Palishkina // Aktual'nye problemy finansovoj bezopasnosti Rossii: Sb. nauch. tr. Tambov: OOO «Konsaltingovaya kompaniya YUkom», 2015. — pp. $47-55$.

[4] Skorikov, D.S. Nalogovye pravonarusheniya kak ugroza ehkonomicheskoj bezopasnosti / D.S. Skorikov // Razrabotka strategii social'noj i ehkonomicheskoj bezopasnosti gosudarstva: Materialy II Vserossijskoj zaochnoj nauchno-prakticheskoj konferencii (1 fevralya 2016 g.). - Kurgan: Izd-vo Kurganskoj GSKHA, 2016. - pp. 204-207.

[5] Smolenceva, E.V. Sovremennye ugrozy nalogovoj bezopasnosti Rossijskoj Federacii/ E.V. Smolenceva // Uspekhi sovremennoj nauki i obrazovaniya. - 2017. - №2 (3). - pp.180-182.

[6] Dorzhdeev, A.V. O proekte zakona Volgogradskoj oblasti «Ob oblastnom byudzhete na 2017 god i na planovyj period 2018 i 2019 godov» URL:. http://volgafin.volgograd.ru/

[7] Federal Tax Service of Russia - Official site. URL:. http://www.nalog/ru

[8] RosBusinessConsulting (КИС) [Electronic source] // Dolg FNS pered byudzhetom. URL: http://www.rbc.ru/economics/11/07/2017/59648ad89a7947d905498a7f (Date of the application: 25.01.2018).

[9] Osnovnye napravleniya byudzhetnoj, nalogovoj i tamozhenno-tarifnoj politiki na 2018 god i planovyj period 2019 i 2020 godov [Electronic source] // https://www.minfin.ru/ru/document/?id_4=119695.

[10] Publichnaya deklaraciya celej i zadach FNS Rossii na 2017 god. Electronic source // URL: https://www.nalog.ru/rn77/about_fts/fts/activities_fts/\#t11 